\title{
Empirical Evidence on the US Labour Market Hysteresis: New Keynesian Wage Phillips Curve (1990-2014)'
}

Leyla BASTAV (https://orcid.org/0000-0003-1533-2289), Banking Regulation and Supervision Agency, Turkey; e-mail: lbastav@bddk.org.tr,bastav06@yahoo.com.tr,bastavl@bilkent.edu.tr

\section{ABD İşgücü Piyasasında Histeresi Etkisi Üzerine Ampirik Bir Çalışma: Yeni Keynesyen Ücret Phillips Eğrisi (1990-2014)2}

\begin{abstract}
This study investigates the concept of hysteresis for the US economy vs natural rate hypothesis during (1990:Q1-2014:Q4). Mainstream economics accepts the natural rate in the long run vs high and persistent unemployment idea of hysteresis. Unit root tests detect the nonstationarity of (un)employment series which may indicate hysteresis. Next, macroeconomic background is presented, and human capital or insider-outsider approaches are explained. With the (NKWPC) model, wage inflation is estimated with (un)employment variables and further with the output gap and growth of excess demand. Results reveal no hysteresis patterns except with the rate of change (ROC) of output during 2001 recession. Demand shocks or labour market factors may be causing nonstationarity of (un)employment according to which economic policy choice should be made regarding: demand management policies vs. labour market measures.
\end{abstract}

Keywords

New Keynesian Economics, Business Cycles, Labour Market Structure, Hysteresis, Time Series Models.

JEL Classification Codes : $\quad$ E12, E24, E32.

Öz

Bu çalışmada ABD ekonomisinde doğal işsizlik oranına karşı histeresi hipotezinin geçerliliği (1990:Q1-2014Q4) dönemi için araştırılmaktadır. Anaakım iktisat uzun dönemde, yüksek ve yapışkan işsizlik histeresi hipotezini değil, doğal oranı benimsemektedir. Birim kök testleri işsizlik/istihdam serilerinde durağan dişıllık tespit etmiştir. Sonra, teorik çerçeve çizilerek, "beşeri sermaye" ve "içeridekiler-dışarıdakiler" hipotezleri de açıklanmıştır. Yeni Keynesyen Ücret Phillips Eğrisi (NKWPC) çerçevesinde ücret enflasyonu işsizlik, istihdam ve daha sonra çıktı açı̆̆ ve çıktı büyüme

1 My special thanks go to Professor Laurence M. Ball from Johns Hopkins University for the valuable comments and suggestions on the theoretical parts of the previous version of this study. I would like to thank Professor John Hunter from Brunel University for valuable comments and suggestions for the econometric estimations. I am also grateful to Professors Bedriye Saraçoğlu, and Şenay Açıgöz from Ankara Hacı Bayram Veli University, Department of Econometrics for their very helpful comments and suggestions. All errors are of course my own responsibility.

2 Öncelikle, bu çalışmanın bir önceki versiyonunda teorik kssımlara yaptı̆̆ yorumlar ve katkıları için Johns Hopkins Üniversitesinden Professor Laurence M. Ball'a özel olarak teşekkür ederim. Brunel Üniversitesinden John Hunter'a ekonometrik tahminlere iliş̧kin değerli yorum ve önerileri için teşekkür etmek isterim. Gene Gazi Üniversitesi Ekonometri Bölümü'nden Bedriye Saraçoğlu ile Şenay Açıkgöz'e yorum ve önerileri ile katkları için şükranlarımı sunarım. Tüm hatalar elbette ki benim sorumluluğumdadır. 
oranı değişkenlerine karşı tahmin edilmiştir. Sonuçlara göre histeresi etkisi bulunmamakta, sadece çıktı büyüme oranı ile 2001 resesyonu esnasında gözlenmektedir. İşsizlik/istihdam serilerindeki durağan dışılığa talep şokları veya işgücü piyasası değişkenleri neden olabileceğinden ekonomi politikası tercihleri buna uygun olarak gerçekleştirilmelidir: talep yönlü politikalar veya işgücü piyasası tedbirleri.

Anahtar Sözcükler $\quad$ : Yeni Keynesyen Ekonomi, Ekonomik Dalgalanmalar, İşgücü Piyasaları, Histeresi Zaman Serisi Modelleri.

\section{Introduction}

Macroeconomic hysteresis refers to the phenomenon of rising level of unemployment raising the natural rate of unemployment permanently during unfavorable times (vice versa for economic booms). Although hysteresis was implicit in the older Keynesian models, where equilibrium was possible at any rate of output with the corresponding rate of inflation, many Keynesians continued to adhere to the "natural rate of unemployment" (NRU) during the 1972-1985 period. After the Lucas attack in 1976, as the Keynesian economics regathered strength during 1985 , more economists came to question the natural rate ${ }^{3}$. Meanwhile a continuous upward trend of European unemployment rates during the 19701980's could be explained neither by conventional classical nor by Keynesian theories' price rigidities and/or menu costs. With the challenge on the notion of the NRU, economists started building alternative theories around "hysteresis" concept.

Hysteresis involved that the changes in NRU were result of changes in cyclical unemployment rather than the developments in the supply side. Mainstream and the Classics emphasized changes in the labour market factors like minimum wages, efficiency wage payments, unemployment benefits, demographical factors etc, whereas defendants of hyststeresis pointed at the changes in aggregate demand as the major factors changing NRU. How the cyclical unemployment would affect NRU has been explained with two major hypotheses of hysteresis: "human capital" and "Insider-Outsider" (IO). Human capital approach asserts that unemployment would lead to deterioration of human capital and falling labour demand by firms, thereby raising the long-term unemployment through time. According to the IO defendants wage bargains would only care for interests of the employed workers demanding higher wages, leaving the outsiders as persistently unemployed.

Considerable amount of research has been conducted on hysteresis following the pioneering work of Blanchard and Summers (1986). The body of empirical work on the subject clusters around two major groups, 1) the statistical studies concentrating on linear/nonlinear unit root (UR) testing, and 2) studies involving econometric estimation of 
structural models. The findings vary for different countries and periods, with more in favor of hysteresis for Europe. So far, only limited information has been accumulated and there is not a well-established theory explaining its dynamics.

This study aims to compile empirical evidence on the matter, as to determine whether there exists any hysteresis dynamics in the wage determination process of the US economy during the post 1990s. Findings will have implications for both theory and policy. The paper examines the theoretical framework related to hysteresis and surveys empirical evidence in the first two sections. Following statistical data analysis and unit root tests, the model is formulated with relevant theoretical extensions and potential econometric issues. Results are reported and evaluated in Sections 4 and 5, and conclusions follow in Section 6.

\section{Theoretical Framework}

How "unemployment" is determined in the markets has two answers related with the period of time in question. Mainstream theory proposes that unemployment is determined by demand management policies, especially monetary policy, in the short-run whereas it is the labour market conditions that determine the level of NRU or NAIRU in the long run. The NRU or NAIRU can change only by changes coming from the supply side of the economy with hardly any effects from demand (Ball, 2009).

In contrast with the classical dichotomy that monetary policy is totally ineffective on unemployment in the long run, there is also the alternative "hysteresis" hypothesis with the assertion that demand management policies can have strong effects on unemployment. According to hysteresis there is a level of NAIRU in the economy with the corresponding steady rate of inflation, however changes in the level of unemployment will also cause NAIRU to change over time (Ball, 2009).

\subsection{The Phillips Curve (PC) Tradeoff}

The idea that amount of money influences the economic activity dates back to 1752 essay of David Hume, where he mentions in his own words that: "It is easy to trace the money in its progress through the whole commonwealth where we shall find that it must first quicken the diligence of every individual, before it increases the price of labour" Today's mainstream theory is much influenced by Hume's views as followed in Milton Friedman's speech (1968) and Robert Lucas' (1996) Nobel prize lecture. According to Friedman there is always a temporary tradeoff between unemployment and inflation, however this tradeoff does not exist in the long run. In the short-run imperfect information, long-term labour contracts, adjustment costs or departures from rationality distort expectations and monetary neutrality assumption of the Classics breaks down. In the long run unemployment returns to NRU (Ball, 2009).

Mainstream economics relies on the accelerationist Phillips curve of Friedman (1968) as in (1) below, where inflation is a function of inflation expectations (adaptive) and detrended unemployment where $\left(\mathrm{U}^{*}\right)$ stands for the NRU. 


$$
\prod=\prod-1+\alpha\left(\mathrm{U}-\mathrm{U}^{*}\right) \quad \alpha<0
$$

As the PC started losing credibility during the 1970s strong arguments emerged against its theoretical and practical validity. However, it reemerged in the theoretical scene in the post 1985s as New Keynesian Phillips Curve (NKPC), in the expectations-augmented form. Today NKPC is based on the basic concepts of rational expectations, price rigidities and intertemporal optimization deriving from Rotemberg (1982) and Calvo (1983) ${ }^{4}$. The model essentially relates inflation to expected inflation and a real activity variable (eg: output gap) as in (4) and (5) below. Two types of NKPC considered are, conventional (4); and hybrid (5) with the backward looking variable $\mathrm{p}_{\mathrm{t}-1}$ (Section 4.1.b; Gali \& Gertler, 1999).

\subsection{Changing NRU or NAIRU}

Majority of economists believe that monetary policy can push $U$ away from $U^{*}$ equation (1) for a few years but changes in unemployment over a decade or longer will be determined by changes in NRU only. Level of NRU is dependant on the labour market structures such as unions, minimum wages, job search etc. According to Monetarists (and the mainstream) monetary policy simply has no effect in determining its level. The NAIRU changes through time have their roots in the supply side developments such as labour market imperfections, institutions, economic shocks and/or globalization (Ball, 2009).

On the other strand defendants of hysteresis emphasize demand side factors in determining NRU or NAIRU with the actual level of unemployment (effected by monetary policy) pulling NRU in its own direction like a magnet. Defendants assert that movements in actual demand, and past levels of actual unemployment will change $\mathrm{U}^{*}$ and will have implications on the long run NAIRU level. (Ball, 2009) For these New Keynesian (NK) academics hysteresis is one other reason for the NAIRU to change over time. Defendants do not refute the mainstream theory, but rather make a contribution to it by adding that the movements in actual demand may also be alternative reasons that cause changes in NAIRU (Ball, 2009).

\subsection{The Record of Unemployment Patterns}

High and persistent unemployment in Europe during the 1980s, unemployment falls in the UK in the 1990s, and different labour market patterns in the US and Europe (which could not previously be explained by labour supply in markets nor by market rigidities) were attempted explanations within the hysteresis framework.

Following the seminal work of Blanchard and Summers (1986), economists like Gottfries and Horn (1987), Gordon (1990), Ball (2009, 1999, 1997) and others like Jaeger and Parkinson (1991), Roed (1999, 1996), (see Section: 3) started working on the concept 
challenging the natural rate and claiming that unemployment is in fact persistent after negative shocks. There is ample empirical evidence collected in favor of the presence of hysteresis, in different countries, during different time periods, however there is hardly a clear understanding of the nature of hysteresis yet, as far as, 1) the mechanisms through which unemployment effects NAIRU, 2) how strength of the effects changes in different times and places, and 3) the implications for monetary policy (Ball, 2009). There is a need for further empirical research to understand essentials of the mechanism and the reasons as to why it exists.

\subsection{Theoretical Approaches on Hysteresis}

Today "human capital" and the insider-outsider (IO) theories are two major approaches around which hysteresis is explained ${ }^{5}$. According to the human capital approach (Hargraves- Heap, 1980; Phelps, 1972), people lose their labour skills through the time they remain unemployed which in turn lowers their chances of getting new jobs in the market. As people get detached from the labour market the number of long-term unemployed increase, causing persistent levels of unemployment.

The more widely recognized IO models of hysteresis are those based on "membership" as first develeoped and discussed in Blanchard and Summers (1986), Lindbeck and Snower (1988) and Gottfries and Horn (1987). These models are based on the asymmetry between insiders who bargain on wages and unemployed outsiders. In a recessionary economy (where the total labour force consists of union members), some of the labour force will be laid off and the union will prefer higher wages, instead of employing more "outsiders" by lowering wages. Outsiders, without bargaining power, cannot influence wage decisions and the labour market will reach a new equilibrium. After the crisis unemployed will not be rehired due to high level of wages, which in turn will raise the level of long-term unemployment.

\section{Empirical Studies on Hysteresis}

In 1986, Blanchard and Summers conducted a pioneering work on hysteresis by analyzing employment and unemployment data for Germany, UK, France and the United States (US) for the period 1953-1984. The study revealed the presence of hysteresis for Germany, UK and France with less strong patterns in the US, using OLS estimation based on a theory founded model.

Various studies have been conducted on the subject for a variety of countries and periods of time. Table: 1 below lists the outstanding research on US (and other countries')

5 Third "physical capital" approach states that reductions in employment after adverse shocks reduces capital stock and thus demand for labour in the following periods, raising long term unemployment. However, the theory has not found many proponents. 
hysteresis in labour markets in the existing literature. Majority of the studies utilize unit root (UR) testing although they differ in the techniques used and assumptions made. Majority of UR studies reveal nonstationarity of the (un)employment series and conclude in favor of hysteresis for European Union countries.

Results on the US are rather mixed. As we observe from the table, UR studies refute hysteresis most of the time, with the exception of Arestis and Mariscal (2000), Cheng et.al. (2011) (only during GR), Bahmani-Oskooee et al. (2018). Interestingly econometric estimations of the five structural models produce evidence in favor of hysteresis spanning a period through 1953-2015. This is in contrast with stationarity findings of UR testing during the same periods. Conflicting results suggest statistical tests may not suffice concluding about the existence of hysteresis, and that micro/macroeconomic theory-based techniques would be more enlightening regarding the dynamics and underlying economic relations. Furthermore, UR results do not provide a clear proof of existing persistence of unemployment in the economy, but rather only provide clues to possible hysteresis.

Table: 1

Empirical Research on Labour Market Hysteresis

\begin{tabular}{|c|c|c|c|c|c|}
\hline AUTHORS & YEAR & MODEL & PERIOD & COUNTRIES & FINDINGS \\
\hline $\begin{array}{l}\text { Blanchard and } \\
\text { Summers }\end{array}$ & 1986 & Microfounded OLS Model & 1953-1984 & Germany, France, UK, US & Exists, but weaker in US \\
\hline $\begin{array}{l}\text { Jaeger and } \\
\text { Parkinson }\end{array}$ & 1991 & Max Likelihood Estimation & $1960-1990$ & Germany, Canada, US & Exists, but weaker in US, Canada \\
\hline Roed & 1996 & UR Testing & 1970-1994 & OECD & Exists in many, except US \\
\hline Mitchell & 1993 & Perron (89) Str Break UR Testing & 1884-1984 & OECD & Exits, except: Japan, US, Australia \\
\hline $\begin{array}{c}\text { Arestis and } \\
\text { Mariscal }\end{array}$ & 2000 & Perron (98) UR Testing & 1960-1997 & OECD & Exists in many, exists in US \\
\hline Ball & 1997 & OLS on Disinflation & $1980-1990$ & OECD & Supporting evidence \\
\hline Ball & 1999 & OLS on Demand & $1979-1985$ & OECD & Supporting evidence \\
\hline Leon-Ledesma & 2002 & Panel UR Testing & 1985-1999 & Eurozone, 51 US States & Exists Eurozone12, NRU in US \\
\hline $\begin{array}{l}\text { Cheng } \\
\text { et al. }\end{array}$ & 2011 & Panel UR Testing & $\begin{array}{l}1976-2010 \\
2007-2011 \\
\end{array}$ & $\begin{array}{c}\text { US, } \\
\text { US States }\end{array}$ & Only exists during GR \\
\hline Gali & 2015 & UR Testing, GMM & 1970-2014 & Euro Area, US & Exists in Euro Area Doesn't exist in US \\
\hline $\begin{array}{l}\text { Bahmani- } \\
\text { Oskooee } \\
\text { et al. }\end{array}$ & 2018 & Nonlinear Quantile UR Testing & 1976-2016 & US, US States & Exists US level Exists in many states \\
\hline Yagan & 2018 & Log linear AR Estimation & $2007-2015$ & US & Employment hysteresis exists \\
\hline
\end{tabular}

\section{Empirical Model}

\subsection{Model, Econometric Approach ${ }^{6}$}

In the paper it is assumed that the dynamic process of wage inflation in the economy is in the form of a Phillips curve as discussed in Section 2.1. In its general form Phillips curve is a relation between rate of change of prices and a real economic indicator like unemployment. Originally Phillips (1958) developed the Phillips curve as a relation between nominal wage inflation and the level of unemployment. Subsequently the term has been used 
to define any relation between the wage or price inflation and a level variable such as unemployment or detrended output (Gordon, 1990).

With the level Phillips curve output will have a tendency to stabilize at equilibrium ${ }^{7}$ with steady nominal demand growth. The NKWPC has been estimated against the unemployment gap variable $\mathrm{UN}_{\text {gap }(\mathrm{t})}$ and its lags to test for the presence of the level's relation. When this relation breaks down, (without a self-correcting mechanism toward the natural rate), economy will settle at any level of output (or unemployment) with the corresponding rate of steady inflation (Gordon, 1990). In the case of lack of level Phillips curve wage inflation will be a function of the rate of change (ROC) of output (unemployment) with hysteresis mechanism at work (Blanchard and Summers, 1986; Gordon, 1990). Therefore wage equations have been alternatively regressed against the $\log$ ratio of $\mathrm{UN}_{\mathrm{t}} / \mathrm{UN}_{\mathrm{t}-1}$ and $\mathrm{UN}_{\mathrm{t}-}$ ${ }_{1} / \mathrm{UN}_{\mathrm{t}-2}$, (i.e. rate of change of unemployment). The rate of change variables will provide us information about the presence of a Phillips curve tradeoff à la Lipsey ${ }^{8}$. Estimations with unemployment have implications for the long-term unemployment or human capital hypothesis, which posits that the newly laid off exert more pressure on wages than the longterm unemployed (Ball, 2009; Blanchard \& Summers, 1986; Llaudes, 2008).

The more widely accepted theory on hysteresis: insider-outsider (IO) hypothesis make a distinction between insiders who are working and the unemployed outsiders. Accordingly, there is a bargaining mechanism between the workers and the firm where the employed set wages just to keep themselves in, without any consideration for outsiders. When an economic shock occurs some of the workers will be laid off and employment will be reduced. This is when insiders renegotiate to raise the level of wages for the new fewer number of workers, which in time maintains a persistent high level of employment in the economy. Even after effects of the negative shock is gone, employment will have no tendency to return to its preshock levels, but rather will persistently be determined by history of shocks (Blanchard \& Summers, 1986: 29). Estimation of the NKPC with employment (N) is important since employment is the variable used for measuring hysteresis on top of an IO theoretical background (Blanchard and Summers, 1986). Thus, the NKWPC equations are alternatively estimated against the $\mathrm{N}$ independent variable in the same manner with UN estimations.

\subsubsection{New Keynesian Wage Phillips Curve à la Gali}

In labour market modeling we follow the NKWPC specification as in Gali (2010):

$$
\mathrm{w}_{\mathrm{t}}=\alpha \mathrm{E}_{\mathrm{t}}\left(\mathrm{p}_{\mathrm{t}+1}\right)-\gamma\left(\mathrm{UN}_{\mathrm{t}}-\mathrm{UN}_{\mathrm{trend}}\right)
$$

7 As per natural rate of Friedman (1968).

8 In his work dated 1960, Lipsey showed that both the level and rate of change of unemployment are the relevant explanatory variables for wage inflation dynamics. 


$$
\mathrm{w}_{\mathrm{t}}=\alpha \mathrm{E}_{\mathrm{t}}\left(\mathrm{p}_{\mathrm{t}+1}\right)+\beta\left(\mathrm{p}_{\mathrm{t}}-\mathrm{p}_{\text {trend }}\right)-\gamma\left(\mathrm{UN}_{\mathrm{t}}-\mathrm{UN}_{\text {trend }}\right)
$$

where wage inflation is a positive function of expected inflation in the next period, and negative function of the detrended unemployment (UN) i.e. the unemployment gap. The equation above has been derived from a series of substitutions of wage markup with unemployment and is similar in spirit with estimations of Blanchard and Summers (1986) The origins of the model date back to Calvo (1983) which is a staggered wage setting model between wage inflation and unemployment. Calvo model is rather an empirically observed one like the original Phillips curve of 1958, without the theoretical foundations. Over the fundamentals of Calvo, Gali (2010) produces a variant of staggered wage setting model (originally developed in Erceg, Henderson and Levin (2000)) instituting the microeconomic foundations with the technical parameters like wage rigidity, labour supply elasticity etc.

The technical variations of the above equations from old Phillips curves like equation (1) above gather around two major issues, 1) equation (1) comes from empirical observations, whereas (2) and (3) follow from the relations of microfounded structural parameters developed under assumptions of staggered wage setting, and 2) above two equations have a forward looking character accounting for expectations, following the rational expectations, rather than the previous curves' adaptive expectations. Equation (3) also accounts for wage stickiness, as in (Gali, 2010). Although it is usual to utilize lagged inflation variable $\mathrm{p}_{\mathrm{t}-1}$ to express wage stickiness, inflation gap (detrended inflation) has been employed as a proxy for inflation persistence following Cogley and Sbordone $(2008)^{10}$.

In our estimations we will follow the model in the above two equations with the reduced form coefficients and will not get into identifying the structural parameters as in Gali (2010). In this sense we follow the approach of Blanchard and Summers (1986) and proceed from a standard format of a Phillips curve (see footnote 8). Thus, wage inflation equation is estimated against four variables, namely: expected price inflation $\mathrm{p}_{\mathrm{t}}$ (rational expectations assumption), inflation gap $\mathrm{p}_{\text {gap }(\mathrm{t})}$, unemployment gap (detrended unemployment) $\mathrm{UN}_{\mathrm{gap}(\mathrm{t})}$ and unemployment gap lagged once $\mathrm{UN}_{\mathrm{gap}(\mathrm{t}-1)}$ (and alternatively

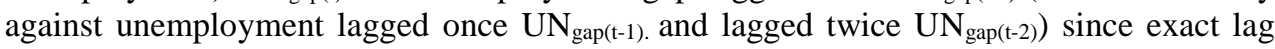
structure of wage dynamics is unknown. Wage equations are also regressed with rate of change of unemployment variables to control for the presence of hysteresis (Blanchard and

9 Blanchard and Summers (1986) develop a model of hysteresis based on the IO theory. Accordingly, there is bargaining process between the employed and a representative firm and the model framework is that of a specific union behavior, with all the technical coefficients. However, their model can also be motivated in other ways. In their own wording: "It is indeed very close to a standard Phillips curve which allows for a rate of change effect à la Lipsey" (Blanchard \& Summers, 1986).

10 Cogley and Sbordone argue that the backward-looking component of the New Keynesian Phillips Curve is criticised for lacking microeconomic foundations and that inflation persistence will be captured better by the detrended inflation variable or inflation gap. Their model has explanatory power for US data for the period 1960-2010. 
Summers, 1986). Altogether there are four real wage equations (and four nominal wage equations) estimated by OLS with the post 2001 dummy variable (Table 4.a).

To analyze the NKWPC further as per the more essential IO approach, eight wage inflation equations are estimated versus employment and rate of change of employment. Results are presented in Table 4.b.

\subsubsection{New Keynesian Phillips Curve à la Nason and Smith}

NKWPC in the spirit of Nason and Smith is as follows: $(2008)^{11}$.

$$
\begin{aligned}
& \mathrm{w}_{\mathrm{t}}=\lambda \mathrm{E}_{\mathrm{t}}\left(\mathrm{p}_{\mathrm{t}+1}\right)+\mu\left(\mathrm{Y}_{\mathrm{t}}-\mathrm{Y}_{\text {trend }}\right) \\
& \mathrm{w}_{\mathrm{t}}=\lambda \mathrm{E}_{\mathrm{t}}\left(\mathrm{p}_{\mathrm{t}+1}\right)+\theta\left(\mathrm{p}_{\mathrm{t}}-\mathrm{p}_{\text {trend }}\right)+\mu\left(\mathrm{Y}_{\mathrm{t}}-\mathrm{Y}_{\text {trend }}\right)
\end{aligned}
$$

Equation (4) follows from the expectations augmented NKPC, after the Lucas critique of 1976, with rational expectations assumption. The NKPC (versus NKWPC) has its theoretical background in Calvo (1983) and Rotemberg (1982). Like equations (2) and (3) the above two equations also possess the microeconomic behavioral coefficients like wage stickiness parameter, discount parameter etc and contain a dynamic character accounting for inflation expectations. In the original NKPC, price inflation is estimated basically as a function of two variables, namely expected price inflation and output gap ( $\mathrm{Y}_{\text {gap }}$ ). Empirically, many researchers (Saz, 2011) have shown that equation (4) provides a better fit for actual inflation when price stickiness has been taken into account, the so-called hybrid NKPC (5). The usual inflation stickiness variable $\mathrm{p}_{\mathrm{t}-1}$ has been proxied by inflation gap (detrended inflation) as in equation (2) in the previous section.

Similar to Section 4.1.1. above we estimate the two equations in standard Phillips curve format without considering the implicit structural form parameters as in Nason and Smith (2008). Thereby five alternative wage inflation equations are estimated with detrended level of output $\mathrm{Y}_{\text {gap }}$ (output gap), rate of change of nominal output $\mathrm{x}_{\mathrm{t}}$, rate of change of real output $\mathrm{q}_{\mathrm{t}}$. Results follow in Tables 4.c and 4.d. The rate of change variables are included for detecting the hysteresis effect at the lack of level effect. Table 4.d also reports results of estimations of the output gap (level) and the rate of change of GNP variables in the same equations to check robustness of the results.

In Tables 4a-4d each equation has been estimated with and without time trend to test for presence of wage inflation movements independent of history of unemployment. 2001Q2 and 2008Q1 structural breaks are checked by Chow test, and stability has further been tested

11 The NKPC was originally formulated with marginal cost, however it has widely been estimated with output gap proxy as well. 
by the cumulative sum of squares (CUSUM). Since all variables are level stationary I(0) estimations are carried out with OLS ${ }^{12}$.

\subsection{Data and Unit Root Tests}

The nominal GNP and GNP price deflator (base year 1982) are obtained from the Bureau of Economic Analysis (BEA) database. Real manufacturing hourly wage, unemployment and employment rate series are from the Bureau of Labour Statistics (BLS) database. All series are quarterly and are seasonally adjusted. All variables are in logarithms. Real wage inflation $\left(\mathrm{w}_{\mathrm{rt}}\right)$, nominal wage inflation, $\left(\mathrm{W}_{\mathrm{nt}}\right)$ and price inflation $\left(\mathrm{p}_{\mathrm{t}}\right)$ are expressed as log ratios of the variables with their own lagged values. The unemployment/employment gap variables are the log ratios of unemployment/employment to their long-term trend. The long-term trend series are obtained by Hodrick Prescott filtering. The rate of change of unemployment/employment is expressed as log ratio of the unemployment/employment by its lagged value.

The output gap variable $\mathrm{Y}_{\text {gap }}$ is the log ratio of nominal to long term trend output, where long term trend output is obtained by Hodrick Prescott filtering. In calculating excess nominal demand growth, the growth of long-term trend output is deducted from the nominal GNP growth. Growth of long-term trend output is also deducted from the growth of real output to compute excess real demand growth series. The long-term trend real output growth series is also obtained by Hodrick Prescott filtering ${ }^{13}$.

Table: 2

\section{Unit Root Test Results with Structural Break}

\begin{tabular}{|c|c|c|c|c|c|c|}
\hline & \multicolumn{6}{|c|}{ Test Statistic Values } \\
\hline & \multicolumn{2}{|c|}{ ADF with endogenous break } & \multicolumn{2}{|c|}{ PP } & \multicolumn{2}{|c|}{ KPSS } \\
\hline & cst & cst \&trend & cst & cst \&trend & cst & cst \&trend \\
\hline $\begin{array}{c}\begin{array}{c}\mathrm{N}_{\mathrm{t}} \\
\text { level }\end{array} \\
\end{array}$ & -3.82 & -3.85 & -0.47 & -0.89 & $0.42(* *)$ & 0.23 \\
\hline $\begin{array}{c}\Delta \mathrm{N}_{\mathrm{t}}(* *) \\
\mathrm{I}(1)\end{array}$ & -6.45 & -6.59 & -6.17 & -6.31 & 0.22 & 0.08 \\
\hline $\begin{array}{r}\mathrm{UN}_{\mathrm{t}} \\
\text { level }\end{array}$ & $-4.00(* *)$ & $-4.78(* *)$ & -1.29 & -1.45 & $0.27(* *)$ & $0.21\left(^{*}\right)$ \\
\hline $\begin{array}{c}\Delta \mathrm{UN}_{\mathrm{t}}(* *) \\
\mathrm{I}(1)\end{array}$ & -4.64 & $-4.78(* * *)$ & -3.86 & -3.83 & 0.13 & 0.07 \\
\hline
\end{tabular}

$(*),(* *),(* * *)$ show stationarity at 1\%, 5\%, 10\% levels of significance respectively.

Employment (N) and unemployment rate (UN) series are checked for stationarity by three unit root tests namely the Augmented Dickey Fuller (ADF) with structural break, Phillips Perron (PP) and Kwiatkowski-Phillips-Schmidt-Shin (KPSS) using EViews9. Results in Table 2 show that there is instability revealed by nonstationarity in the form of a

12 The issue of endogeneity has been addressed in footnote 13.

13 For both level and rate of change of output variables Hodrick Prescott filtering extracts a pure measure of aggregate supply from the series. 
unit root in both of the series. Employment and unemployment series are both integrated of order one I(1). The nonstationarity of the series imply the possible presence of hysteresis.

Below, variables of the wage equations are tested for a unit root by ADF-GLS, PP and KPSS tests. Test results in Table 2 reveal that the variables are stationary $\mathrm{I}(0)$, at least as per two tests.

Table: 3

Unit Root Test Results

\begin{tabular}{|c|c|c|c|c|c|c|}
\hline & \multicolumn{6}{|c|}{ Test Statistic Values } \\
\hline & \multicolumn{2}{|c|}{ ADF-GLS } & \multicolumn{2}{|c|}{ PP } & \multicolumn{2}{|c|}{ KPSS } \\
\hline & Cst & cst\&trnd & Cst & cst\&trnd & cst & cst\&trnd \\
\hline & \multicolumn{6}{|c|}{ Level Stationary Variables I(0) } \\
\hline $\mathrm{W}_{\mathrm{rt}}$ real wage inflation & -10.16 & -10.17 & -10.34 & -10.27 & 0.066 & 0.066 \\
\hline $\mathrm{W}_{\mathrm{nt}}$ nominal wage inflation & -9.86 & -6.74 & -11.89 & -11.87 & 0.096 & 0.076 \\
\hline $\mathrm{p}_{\mathrm{t}}$ inflation & $-1.26(*)$ & $-2.38(*)$ & -5.02 & -5.03 & 0.14 & 0.12 \\
\hline pgap(t) inflation gap & -6.14 & -6.33 & -7.37 & -7.32 & 0.059 & 0.036 \\
\hline $\mathrm{UN}_{\text {gap (t) }}$ unemployment gap & -2.86 & -3.43 & $-2.85(* *)$ & $-2.85(*)$ & 0.05 & 0.04 \\
\hline $\mathrm{N}_{\text {gap }(t)}$ employment gap & -2.21 & $-2.79(* *)$ & -3.11 & $-3.05(*)$ & 0.04 & 0.04 \\
\hline $\log \left(\mathrm{UN}_{\mathrm{t}} / \mathrm{UN}_{\mathrm{t}-1}\right)$ roc unemployment & -4.03 & -4.03 & -4.06 & -4.04 & 0.13 & 0.07 \\
\hline $\log \left(\mathrm{UN}_{\mathrm{t}-1} / \mathrm{UN}_{\mathrm{t}-2}\right)$ roc unemployment & -4.07 & -4.11 & -4.10 & -4.12 & 0.15 & 0.07 \\
\hline $\log \left(\mathrm{N}_{\mathrm{t}} / \mathrm{N}_{\mathrm{t}-1}\right)$ roc employment & -3.03 & -3.33 & -6.14 & -6.28 & 0.23 & 0.08 \\
\hline $\log \left(\mathrm{N}_{\mathrm{t}-1} / \log \mathrm{N}_{\mathrm{t}-2}\right)$ roc employment & -3.10 & -3.30 & -6.10 & -6.27 & 0.24 & 0.09 \\
\hline $\mathrm{x}_{\mathrm{t}}$ excess nominal GNP growth & -3.29 & -3.63 & -6.83 & -6.84 & 0.06 & 0.04 \\
\hline $\mathrm{q}_{\mathrm{t}}$ excess real GNP growth & -4.13 & -4.20 & -7.41 & -7.48 & 0.10 & 0.04 \\
\hline$Y_{\text {gap }}$ level of detrended output & -2.50 & -3.47 & -3.44 & $-3.39(* *)$ & 0.04 & 0.04 \\
\hline
\end{tabular}

(*) Variables are stationary at 5\% level of significance, (*) shows nonstationarity variable.

(**) Shows stationarity at $10 \%$ level of significance

\subsection{First Glance at the Data}

Before moving on with the more formal econometric analysis, simple statistics and graphical tools are used to search the prima facie PC relationship between the real economy variables and wage inflation. Time graph of unemployment and employment are presented in Figure: 1 in Appendix I. As observed in the graphs and the UR test results, series are nonstationary.

In Figure: 2 in the Appendix, there is the scatterplot of unemployment and employment versus wage inflation. As can be followed from the plots, there does not appear a strong negative relationship with unemployment and the correlation between the two series is -0.29 . The coefficient of correlation for employment is higher as 0.42 .

In the following graph in Figure: 3, there is the ROC of unemployment and ROC of unemployment (lagged) against wage inflation. As per the graphs, correlation coefficients for rate of change of unemployment and wage inflation are not so high as 0.19 and 0.20 respectively and are with the wrong sign. For ROC of employment and ROC of employment (lagged) coefficients are -0.16 and 0.007 respectively, again with the wrong sign or too low to be considered at all. The correlation coefficients in the subperiods for 1990-2007 and 2007-2014 are neither statistically significant nor economically meaningful. Thus, preliminary evidence in favor of rate of change PC for hysteresis seems weak. From here on we move to the more formal analysis of econometric model estimation. 


\section{Findings}

\subsection{OLS Estimation Results}

Estimation coefficients of the NKWPC equation are provided in Tables 4a-4b. Results do not reveal significant statistical relationship either between wage inflation and

level of unemployment/employment or wage inflation and ROC of unemployment/employment variables. Estimated coefficients are statistically insignificant and do not posses meaningful signs. The post 2001 slope dummy is significant in only one equation in Table 4.a and in half of the equations of Table 4.b.

The first equation in Table 4.c reveals that excess nominal GNP growth rate $x_{t}$ is statistically significant and economically meaningful, only during the 2001 recession. As the rate of change of excess nominal GNP growth increases 1 percentage point, real wages will rise by 0.34 percent. Although with relatively high t value of $(-1.75)$, the excess real GNP growth rate $q_{t}$ has not proved to be significant. The level of detrended output $\left(\mathrm{Y}_{\mathrm{gap}}\right)$ in equation three is insignificant. Results are similar for the nominal wage equations. The $\mathrm{R}^{2}$ 's are 0.39 and 0.27 for the first and fourth equations and all equations on the overall are significant by the F test. The post 2001 time dummy variables are significant throughout the equations in Tables $4 c-4 d$.

Output gap equations are further tested by inclusion of level and rate of change of output variables in the same equation (Table 4.d). The findings in Table 4.d are robust when the output gap $Y_{\text {gap }}$ and rate of change of nominal output $x_{t}$ are in the same equation. The results presented in column one and three show that the $\mathrm{x}_{\mathrm{t}}$ variable is significant with a coefficient of 0.35 during the 2001 recession. The findings are similar for nominal wages and are indicative of hysteresis that wage inflation responds to the rate of increase of output rather than to its level during 2001. Like equations in Table 4.c only CUSUM of squares has registered instability which has been eliminated with the inclusion of the 2001 dummy variable ${ }^{14}$. The $R^{2}$ s are 0.39 and 0.27 respectively and equations on the overall are significant although the F-statistics have fallen somewhat.

The trend variable in the wage equations have found to be insignificant and not been reported at all. From among time dummy variables for 2001 and 2008, only the 2001 one is found to be significant in the equations of Table $4 \mathrm{a}-4 \mathrm{~d}$. Although the Chow test has not revealed any breakpoints, CUSUM of squares test has diagnosed instability within the estimation period which has disappeared to a great extent with the inclusion of the 2001 time dummy. F-statistics reveal overall significance.

The stability and robustness of the estimated equations through tables $4 a-4 d$ support the case that these models are at least weakly exogenous for the parameters of interest. Since the relations are invariant, this is coherent with super exogeneity. 
Results donot give information due to the existence of the NKWPC à la Gali and neither to the existence of the PC with employment. However, coefficients of the lagged unemployment gap and the lagged employment gap variables of -0.03 and 0.19 with $t$ values above one (Tables $4 \mathrm{a}$ and $4 \mathrm{~b}$ equations 5 and 6 ) imply possible level PC tradeoff. This implication is also supported by the correlation coefficients of -0.29 and 0.42 (see Section 4.3). Previous findings of valid NKWPC ${ }^{15}$ together with findings of this paper may point at relevance of higher order lags in PC estimations.

NKWPC estimation à la Nason and Smith (2008) for wage inflation and the output gap tradeoff did not prove significant neither with the level nor ROC variables. Wage inflation (real and nominal) is explained by ROC of nominal output $x_{t}$, , only during the 2001 recession, implying hysteresis. Variable $x_{t}$ is robust to inclusion of the output gap variable $\mathrm{Y}_{\text {gap }}$ in the regression equation (Table 4.d).

Table: $4 a$

NKWPC with Unemployment Gap and ROC Unemployment ${ }^{(1)}$

\begin{tabular}{|c|c|c|c|c|c|c|c|c|}
\hline & $\mathrm{w}_{\mathrm{rt}}$ & $w_{r t}$ & $w_{r t}$ & $\mathrm{w}_{\mathrm{rt}}$ & $\mathrm{W}_{\mathrm{nt}}$ & $\mathrm{W}_{\mathrm{nt}}$ & $\mathrm{W}_{\mathrm{nt}}$ & $\mathrm{W}_{\mathrm{nt}}$ \\
\hline Constant & $\begin{array}{l}0.004 \\
(2.48) \\
\end{array}$ & $\begin{array}{l}0.005 \\
(2.51) \\
\end{array}$ & $\begin{array}{l}0.005 \\
(2.48) \\
\end{array}$ & $\begin{array}{l}0.005 \\
(2.32) \\
\end{array}$ & $\begin{array}{l}0.004 \\
(2.48) \\
\end{array}$ & $\begin{array}{l}0.004 \\
(2.37) \\
\end{array}$ & $\begin{array}{l}0.005 \\
(2.48) \\
\end{array}$ & $\begin{array}{l}0.005 \\
(1.82) \\
\end{array}$ \\
\hline $\begin{array}{c}\text { expected inflation } \\
p_{t}\end{array}$ & $\begin{array}{c}-0.80 \\
(-2.61)\end{array}$ & $\begin{array}{c}-0.88 \\
(-2.52)\end{array}$ & $\begin{array}{c}-0.87 \\
(-2.71)\end{array}$ & $\begin{array}{c}-0.87 \\
(-2.43)\end{array}$ & $\begin{array}{c}0.20 \\
(0.66)\end{array}$ & $\begin{array}{c}0.14 \\
(0.40)\end{array}$ & $\begin{array}{c}0.13 \\
(0.42)\end{array}$ & $\begin{array}{c}0.13 \\
(0.28)\end{array}$ \\
\hline pgap & $\begin{array}{l}-0.007 \\
(-2.31)\end{array}$ & $\begin{array}{l}-0.007 \\
(-2.16) \\
\end{array}$ & $\begin{array}{l}-0.007 \\
(-2.34)\end{array}$ & $\begin{array}{l}-0.007 \\
(-2.19) \\
\end{array}$ & $\begin{array}{l}-0.007 \\
(-2.31)\end{array}$ & $\begin{array}{l}-0.007 \\
(-2.18)\end{array}$ & $\begin{array}{l}-0.007 \\
(-2.34)\end{array}$ & $\begin{array}{l}-0.007 \\
(-2.88)\end{array}$ \\
\hline $\mathrm{un}_{\text {gap }}$ & $\begin{array}{c}0.03 \\
(1.16)\end{array}$ & & & & $\begin{array}{c}0.03 \\
(1.16)\end{array}$ & & & \\
\hline $\mathrm{un}_{\mathrm{gap}(t-1)}$ & $\begin{array}{c}-0.03 \\
(-1.09)\end{array}$ & $\begin{array}{c}0.01 \\
(0.77) \\
\end{array}$ & & & $\begin{array}{c}-0.03 \\
(-1.09)\end{array}$ & $\begin{array}{c}0.01 \\
(0.48)\end{array}$ & & \\
\hline $\mathrm{un}_{\mathrm{gap}(t-2)}$ & & $\begin{array}{c}-0.02 \\
(-0.85)\end{array}$ & & & & $\begin{array}{c}-0.01 \\
(-0.52)\end{array}$ & & \\
\hline $\log \left(u n_{t} / u_{t-1}\right)$ & & & $\begin{array}{c}0.02 \\
(0.96)\end{array}$ & & & & $\begin{array}{c}0.02 \\
(0.96)\end{array}$ & \\
\hline $\log \left(\mathrm{un}_{\mathrm{t}-1} / \mathrm{un}_{\mathrm{t}-2}\right)$ & & & & $\begin{array}{l}0.009 \\
(0.41)\end{array}$ & & & & $\begin{array}{c}0.01 \\
(0.52)\end{array}$ \\
\hline $\begin{array}{c}2001^{(2)} \\
\text { time dummy }\end{array}$ & $\begin{array}{c}8.6 \mathrm{E}-05 \\
(1.46)\end{array}$ & $\begin{array}{l}-0.03^{(3)} \\
(-1.42)\end{array}$ & $\begin{array}{c}8.9 \mathrm{E}-05 \\
(1.41)\end{array}$ & $\begin{array}{l}0.08^{(3)} \\
(2.31)\end{array}$ & $\begin{array}{c}8.6 \mathrm{E}-05 \\
(1.46)\end{array}$ & $\begin{array}{l}0.0001 \\
(1.89)\end{array}$ & $\begin{array}{c}8.9 \mathrm{E}-05 \\
(1.41)\end{array}$ & $\begin{array}{l}0.0001 \\
(1.22)\end{array}$ \\
\hline $\mathrm{N}$ & 97 & 96 & 97 & 96 & 97 & 96 & 97 & 96 \\
\hline $\mathrm{R}^{2}$ & 0.33 & 0.31 & 0.33 & 0.32 & 0.19 & 0.18 & 0.19 & 0.18 \\
\hline F-Statistic ${ }^{(4)}$ & 8.91 & 8.16 & 11.18 & 10.87 & 4.27 & 3.95 & 5.33 & 4.97 \\
\hline \multicolumn{9}{|c|}{ Diagnostic Tests } \\
\hline Breusch-Godfrey Serial Correlation & 24.07 & 23.22 & 22.68 & 22.56 & 24.07 & 23.23 & 22.68 & 22.56 \\
\hline White Test Heteroscad & 25.16 & 33.43 & 23.54 & 20.67 & 25.16 & 33.43 & 23.54 & 20.67 \\
\hline \multicolumn{9}{|c|}{ Stability Tests (F-statistic, LLR) } \\
\hline Chow Test (2) & 0.81 & 0.69 & 0.91 & 0.61 & 0.81 & 0.69 & 0.91 & 0.61 \\
\hline Cnow Iest - ? & 9.17 & 7.88 & 7.93 & 5.39 & 9.17 & 7.88 & 7.93 & 5.39 \\
\hline CUSUM of squares ${ }^{(2)}$ & stable & stable & stable & stable & stable & stable & stable & stable \\
\hline
\end{tabular}

In Tables 4a-4d: (1) $t$ statistics in parenthesis. ${ }^{(2)}$ Chow test with 2001 and 2008 recession breaks; but no breaks detected by the test. Still equations became stable with inclusion of 2001 dummy through $4 a-4 c .{ }^{(3)}$ Slope dummy (4) Overall significant by F test.

Findings come with economic implications. Since NKWPC (2) is not validated by unemployment/employment variables, there does not emerge evidence in favor of level PC.

15 Gali (2010) has detected NKWPC relation for the US during the 1984-2009 period of Great Moderation, with low and stable inflation. 
However evidence in favor of hysteresis is even weaker with only significant ROC of excess output during the 2001 recession. During 2001 there are relevance of demand management policies, especially of the monetary policy. Hysteresis implies that economy would settle at any level of output/unemployment (with corresponding steady inflation rate) depending on the past values of wage inflation and output. Acceleration/decelaration of wage inflation emanates from demand side of the economy at the presence of hysteresis.

\section{Table: $4 \mathrm{~b}$}

NKWPC with Employment Gap and ROC Employment ${ }^{(1)}$

\begin{tabular}{|c|c|c|c|c|c|c|c|c|}
\hline & $\mathrm{w}_{\mathrm{rt}}$ & $\mathrm{W}_{\mathrm{rt}}$ & $\mathrm{w}_{\mathrm{rt}}$ & $\mathrm{W}_{\mathrm{rt}}$ & $\mathrm{W}_{\mathrm{nt}}$ & $\mathrm{W}_{\mathrm{nt}}$ & $\mathrm{W}_{\mathrm{nt}}$ & $\mathrm{W}_{\mathrm{nt}}$ \\
\hline constant & $\begin{array}{l}0.004 \\
(2.49)\end{array}$ & $\begin{array}{l}0.005 \\
(2.32)\end{array}$ & $\begin{array}{l}0.004 \\
(2.45)\end{array}$ & $\begin{array}{l}0.004 \\
(2.43)\end{array}$ & $\begin{array}{l}0.004 \\
(2.49)\end{array}$ & $\begin{array}{l}0.005 \\
(2.32)\end{array}$ & $\begin{array}{l}0.004 \\
(2.45)\end{array}$ & $\begin{array}{l}0.004 \\
(2.43)\end{array}$ \\
\hline $\begin{array}{c}\text { expected inflation } \\
\mathrm{p}_{\mathrm{t}}\end{array}$ & $\begin{array}{c}-0.84 \\
(-2.74)\end{array}$ & $\begin{array}{c}-0.88 \\
(-2.43)\end{array}$ & $\begin{array}{l}-0.81 \\
-2.63 \\
\end{array}$ & $\begin{array}{c}-0.83 \\
(-2.37)\end{array}$ & $\begin{array}{c}0.16 \\
(0.52)\end{array}$ & $\begin{array}{c}0.12 \\
(0.35)\end{array}$ & $\begin{array}{c}0.19 \\
(0.62) \\
\end{array}$ & $\begin{array}{c}0.17 \\
(0.48)\end{array}$ \\
\hline pgap & $\begin{array}{l}-0.007 \\
(-2.33)\end{array}$ & $\begin{array}{l}-0.007 \\
(-2.17)\end{array}$ & $\begin{array}{l}-0.007 \\
(-2.36)\end{array}$ & $\begin{array}{c}-0.01 \\
(-2.13)\end{array}$ & $\begin{array}{l}-0.007 \\
(-2.33)\end{array}$ & $\begin{array}{l}-0.007 \\
(-2.17)\end{array}$ & $\begin{array}{l}-0.007 \\
(2.36)\end{array}$ & $\begin{array}{l}-0.007 \\
(-2.13)\end{array}$ \\
\hline $\mathrm{n}_{\text {gap }}$ & $\begin{array}{l}-0.17 \\
(0.87)\end{array}$ & & & & $\begin{array}{c}-0.17 \\
(-0.78)\end{array}$ & & & \\
\hline $\mathrm{n}_{\text {gap }(t-1)}$ & $\begin{array}{c}0.21 \\
(0.87)\end{array}$ & $\begin{array}{c}0.19 \\
(1.06)\end{array}$ & & & $\begin{array}{c}0.21 \\
(0.87)\end{array}$ & $\begin{array}{c}0.19 \\
(1.06)\end{array}$ & & \\
\hline $\mathrm{n}_{\text {gap }(t-2)}$ & & $\begin{array}{c}-0.16 \\
(-0.85)\end{array}$ & & & & $\begin{array}{c}-0.16 \\
(-0.85)\end{array}$ & & \\
\hline $\log \left(n_{t} / n_{t-1}\right)$ & & & $\begin{array}{c}-0.16 \\
(-0.71)\end{array}$ & & & & $\begin{array}{c}-0.16 \\
(-0.71) \\
\end{array}$ & \\
\hline $\log \left(\mathrm{n}_{\mathrm{t}-1} / \mathrm{n}_{\mathrm{t}-2}\right)$ & & & & $\begin{array}{c}0.12 \\
(0.71)\end{array}$ & & & & $\begin{array}{c}0.12 \\
(0.71)\end{array}$ \\
\hline $\begin{array}{l}2001^{(2)} \\
\text { time dummy }\end{array}$ & $\begin{array}{c}0.0001 \\
(1.87)\end{array}$ & $\begin{array}{l}0.0001 \\
(3.00)\end{array}$ & $\begin{array}{c}0.0001 \\
(1.79)\end{array}$ & $\begin{array}{c}0.0001 \\
(3.24)\end{array}$ & $\begin{array}{c}0.0001 \\
(1.87)\end{array}$ & $\begin{array}{c}0.0001 \\
(3.00)\end{array}$ & $\begin{array}{l}0.0001 \\
(1.79) \\
\end{array}$ & $\begin{array}{c}0.0001 \\
(3.24) \\
\end{array}$ \\
\hline $\mathrm{N}$ & 97 & 96 & 97 & 96 & 97 & 96 & 97 & 96 \\
\hline $\mathrm{R}^{2}$ & 0.33 & 0.33 & 0.32 & 0.32 & 0.19 & 0.19 & 0.18 & 0.18 \\
\hline F-Statistic ${ }^{(4)}$ & 8.79 & 8.68 & 10.99 & 10.81 & 4.17 & 4.09 & 5.17 & 5.03 \\
\hline \multicolumn{9}{|c|}{ Diagnostic Tests } \\
\hline Breusch-Godfrey Serial Correlation & 22.26 & 20.58 & 21.61 & 19.93 & 22.26 & 20.58 & 21.61 & 19.93 \\
\hline White Test Heteroscadasticity & 28.95 & 25.44 & 25.88 & 17.83 & 28.95 & 25.44 & 25.88 & 17.83 \\
\hline \multicolumn{9}{|c|}{ Stability Tests (F-statistic, LLR) } \\
\hline Chow Test ${ }^{(2)}$ & $\begin{array}{l}078 \\
8.86\end{array}$ & $\begin{array}{l}0.68 \\
7.74\end{array}$ & $\begin{array}{l}0.76 \\
6.72\end{array}$ & $\begin{array}{l}0.59 \\
5.26\end{array}$ & $\begin{array}{l}0.78 \\
8.86\end{array}$ & $\begin{array}{l}0.68 \\
7.74\end{array}$ & $\begin{array}{l}0.76 \\
6.72\end{array}$ & $\begin{array}{l}0.59 \\
5.26\end{array}$ \\
\hline CUSUM of squares ${ }^{(2)}$ & Stable & stable & stable & stable & stable & stable & stable & stable \\
\hline
\end{tabular}

Table: $4 c$

NKWPC with Output Gap/Excess Output Growth ${ }^{(1)}$

\begin{tabular}{|c|c|c|c|c|c|c|}
\hline & $\mathrm{W}_{\mathrm{rt}}$ & $\mathrm{W}_{\mathrm{rt}}$ & $\mathrm{W}_{\mathrm{rt}}$ & $\mathrm{W}_{\mathrm{nt}}$ & $\mathrm{W}_{\mathrm{nt}}$ & $\mathrm{W}_{\mathrm{nt}}$ \\
\hline constant & $\begin{array}{l}0.006 \\
(3.32)\end{array}$ & $\begin{array}{l}0.005 \\
(3.08) \\
\end{array}$ & $\begin{array}{l}0.003 \\
(1.99)\end{array}$ & $\begin{array}{l}0.006 \\
(3.32)\end{array}$ & $\begin{array}{l}0.005 \\
(3.08)\end{array}$ & $\begin{array}{l}0.003 \\
(1.99) \\
\end{array}$ \\
\hline $\begin{array}{c}\text { expected inflation } \\
\mathrm{p}_{\mathrm{t}}\end{array}$ & $\begin{array}{c}-0.63 \\
(-1.98)\end{array}$ & $\begin{array}{c}-0.98 \\
(-3.21)\end{array}$ & $\begin{array}{c}-0.64 \\
(-2.06)\end{array}$ & $\begin{array}{c}0.37 \\
(1.18)\end{array}$ & $\begin{array}{c}0.02 \\
(0.05) \\
\end{array}$ & $\begin{array}{c}0.36 \\
(1.14) \\
\end{array}$ \\
\hline pgap & $\begin{array}{l}-0.006 \\
(-2.55)\end{array}$ & $\begin{array}{l}-0.006 \\
(-2.50)\end{array}$ & $\begin{array}{l}-0.007 \\
(-2.15)\end{array}$ & $\begin{array}{l}-0.006 \\
(-2.55)\end{array}$ & $\begin{array}{l}-0.006 \\
(-2.50)\end{array}$ & $\begin{array}{l}-0.007 \\
(-2.15)\end{array}$ \\
\hline $\begin{array}{c}\text { excess nominalgrowth } \\
\mathrm{x}_{\mathrm{t}}\end{array}$ & $\begin{array}{c}-0.41 \\
(-2.06)\end{array}$ & & & $\begin{array}{c}-0.41 \\
(-2.06)\end{array}$ & & \\
\hline $\begin{array}{l}\text { excess real growth } \\
\mathrm{q}_{\mathrm{t}}\end{array}$ & & $\begin{array}{c}-0.37 \\
(-1.75)\end{array}$ & & & $\begin{array}{c}-0.37 \\
(-1.75)\end{array}$ & \\
\hline $\begin{array}{c}\text { detrended output } \\
\mathrm{Y}_{\text {gap }}\end{array}$ & & & $\begin{array}{c}-0.07 \\
(-1.01)\end{array}$ & & & $\begin{array}{l}-0.07 \\
(-1.01) \\
\end{array}$ \\
\hline $\begin{array}{c}2001 \\
\text { time dummy } \\
\end{array}$ & $\begin{array}{l}0.75^{(3)} \\
(2.71)\end{array}$ & $\begin{array}{c}9.9 \mathrm{E}-05 \\
(2.04)\end{array}$ & $\begin{array}{l}0.0001 \\
(3.41)\end{array}$ & $\begin{array}{l}0.75^{(3)} \\
(2.71)\end{array}$ & $\begin{array}{c}9.9 \mathrm{E}-05 \\
(2.04)\end{array}$ & $\begin{array}{c}0.0001 \\
(3.41)\end{array}$ \\
\hline $\mathrm{N}$ & 97 & 97 & 97 & 97 & 86 & 97 \\
\hline $\mathrm{R}^{2}$ & 0.39 & 0.39 & 0.32 & 0.27 & 0.26 & 0.19 \\
\hline F-Statistic ${ }^{(4)}$ & 14.76 & 14.60 & 11.06 & 8.30 & 8.16 & 5.23 \\
\hline \multicolumn{7}{|c|}{ Diagnostic Tests } \\
\hline Breusch-Godfrey Serial Correlation & 23.15 & 23.15 & 19.74 & 23.15 & 23.15 & 19.74 \\
\hline White Test Heteroscad & 56.33 & 49.45 & 15.74 & 56.33 & 49.45 & 15.74 \\
\hline \multicolumn{7}{|c|}{ Stability Tests (F-statistic, LLR) } \\
\hline Chow Test ${ }^{(2)}$ & 1.14 & 1.14 & 0.69 & 1.14 & 1.14 & 0.69 \\
\hline Chow lest & 9.92 & 9.92 & 6.13 & 9.92 & 9.92 & 6.13 \\
\hline CUSUM of squares ${ }^{(2)}$ & stable & stable & stable & stable & stable & stable \\
\hline
\end{tabular}


Table: 4d

NKWPC with Output Gap and Excess Output Growth ${ }^{(1)}$

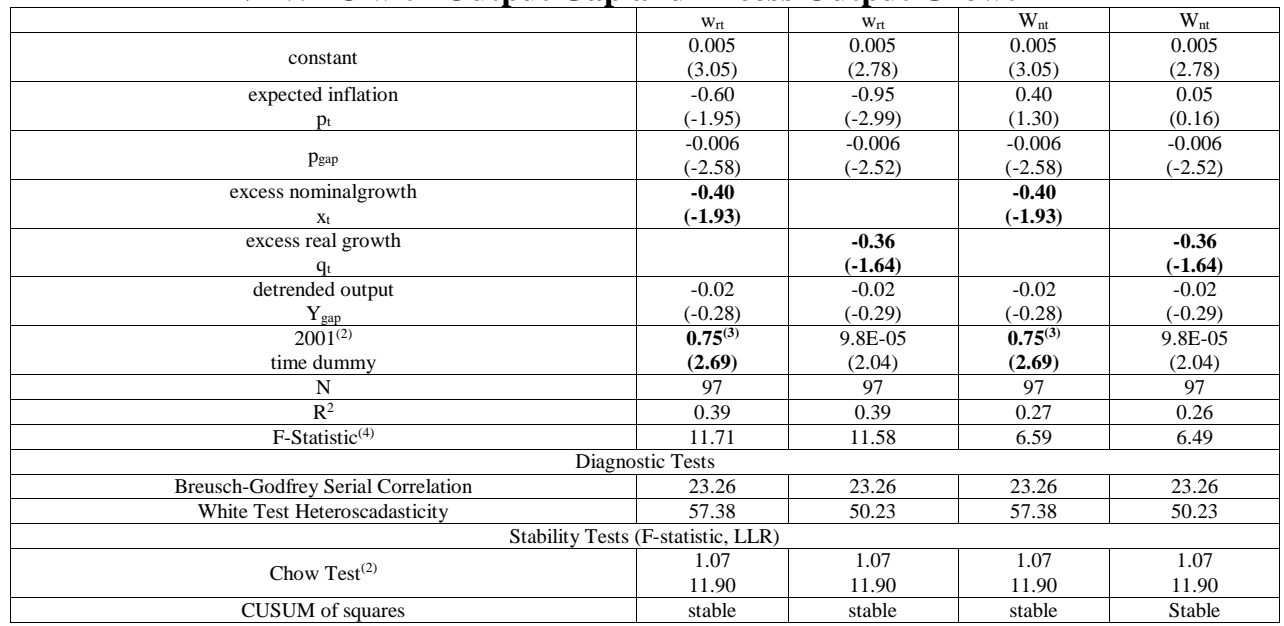

\subsection{Patterns of Labour Market Turnover and Long-Term Unemployment}

This section examines US labour market structure further in terms of turnover and long-term unemployment. High rate of turnover in labour markets will provide evidence against the IO approach when period of unemployment is short and unemployed get hired shortly. By contrast low turnover with high rates of long term unemployed would support the IO theories.

Figure 1 below gives the rate of total separations (as share of total employment) for the nonfarm labour force for the period: 2001-2014 ${ }^{16}$. The data is further broken into "layoffs and discharges" versus "quit" rates in Figure 2. Total separations are those excluded from payroll during the last calendar month. As unemployment rises (Figure: 4) like during 2001 and 2008 recessions, total separations tend to decline (involuntary layoffs and discharges rising but voluntary quit rates declining: Figures 2 and 3). The rise in involuntary layoffs and discharges are especially remarkable in the post 2008 recession period.

The decline of total separations with rising unemployment indicates that there is insufficient job creation in the economy during recessions. This leads to a structure where long term unemployment rises with rising unemployment in the labour market. As a matter of fact, long term unemployment has actually risen following the 1990-91, 2001 and especially 2008 recessions (Figure: 3 ). When the average unemployment rate was 5.78 the average of long-term unemployment rate has been 19.8 in 2008; which has risen to 9.28 
percent and 32.5 percent respectively in 2009; 9.63 and 43.7 in 2010; and finally, to 8.98 and 44.2 percent in 2011. However, with falling unemployment from 2011 onwards, the long-term unemployment has receded to 25.8 percent by end of 2016 .

Figure: 1

Turnover Rate (Total Rate of Separations) (\%)

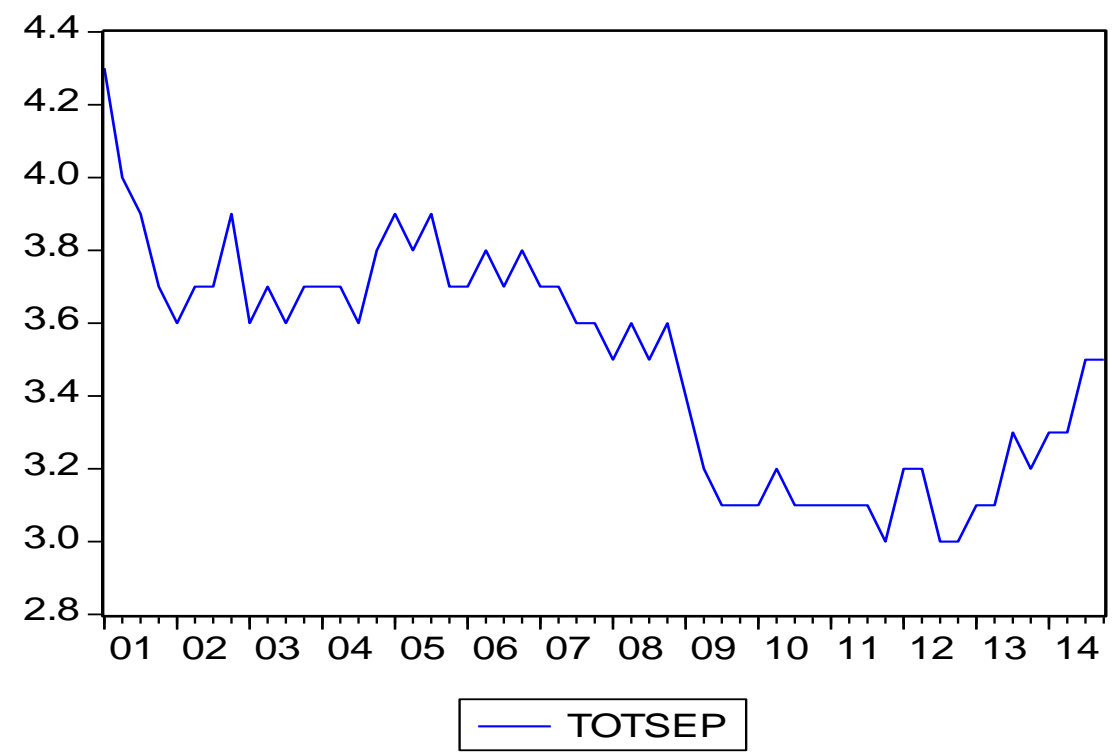

Source: BLS

Figure: 2

Total Rate of Layoffs Discharges, Total Quit Rates (\%)
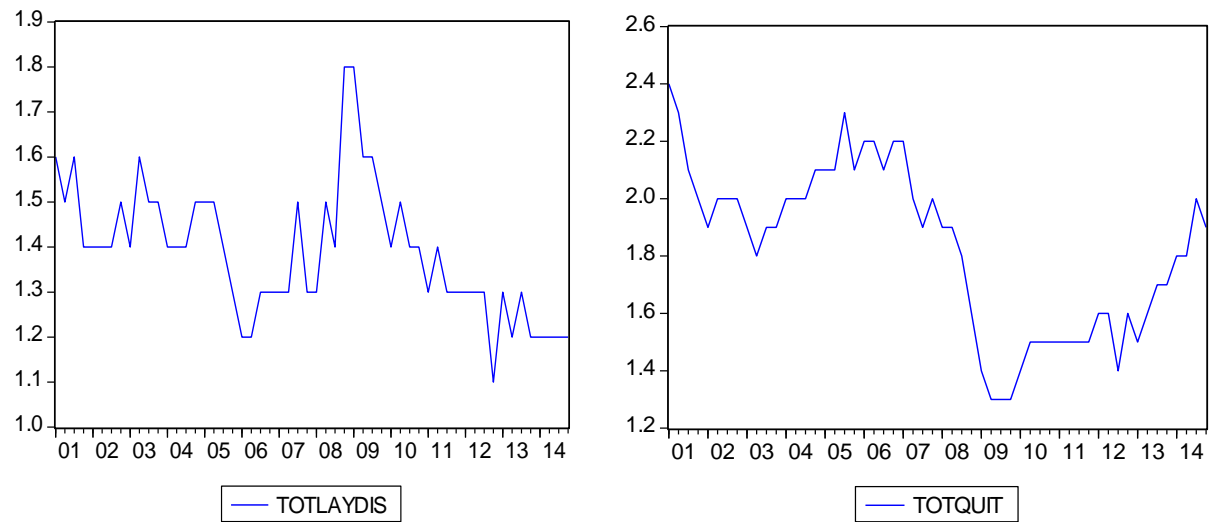

Source: $B L S$ 
Figure: 3

Long Term Unemployment Series ${ }^{(1)}$

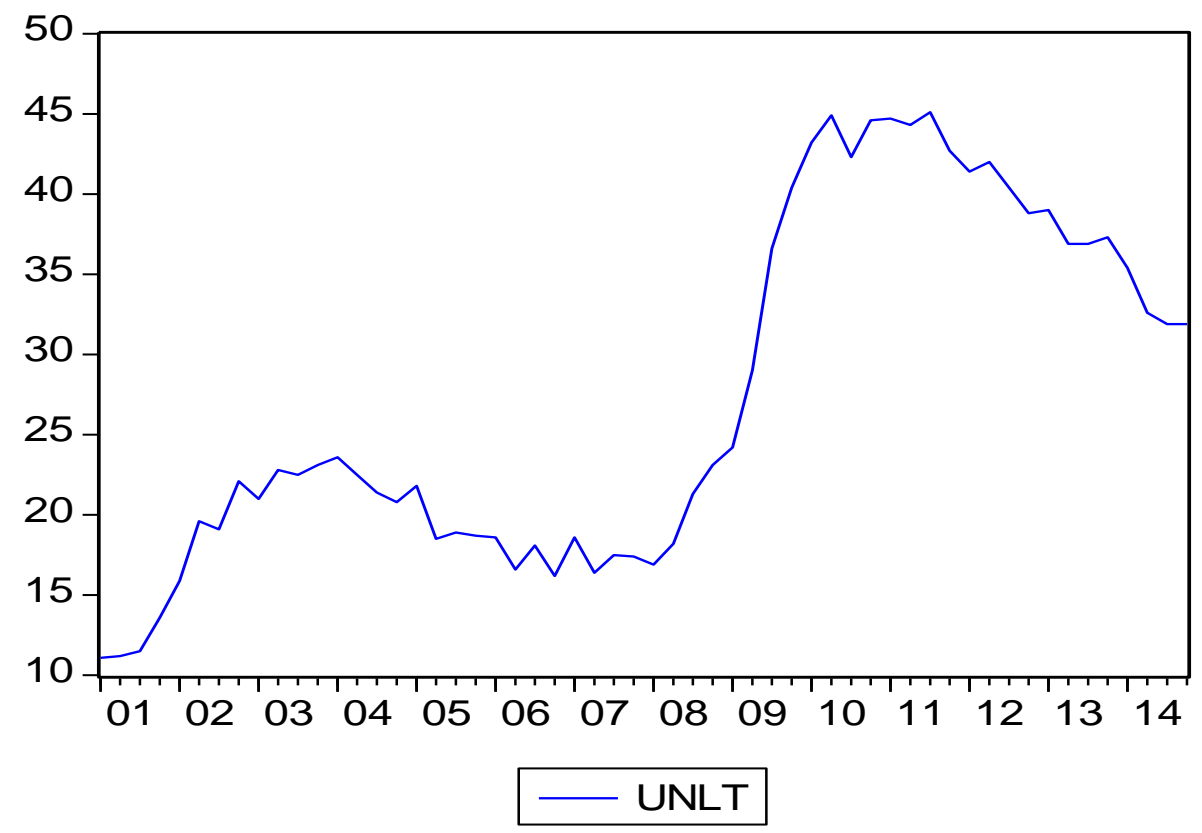

(1) Of total unemployed, percent of unemployed for 27 weeks or more.

Source: $B L S$

Declining turnover vis-a-vis rising unemployment during recessions leading to high rates of long-term unemployment is viewed as evidence in favor of the IO approach. It is true that there exists a labour union dominated bargaining and wage setting structure in the US which leads one to consider the IO approach to be meaningful.

On the other hand, as in Figure 4 below, unemployment rises persistently during recessions ${ }^{17}$ and falls in the following years. The rising and prolonging unemployment during downturns leads us to think whatever the triggering factor of emerging persistence may be it is symptomatic of the business cycles. This intuitively implies validity of demand management policies by the economic management. 
Figure: 4

\section{Unemployment Series}

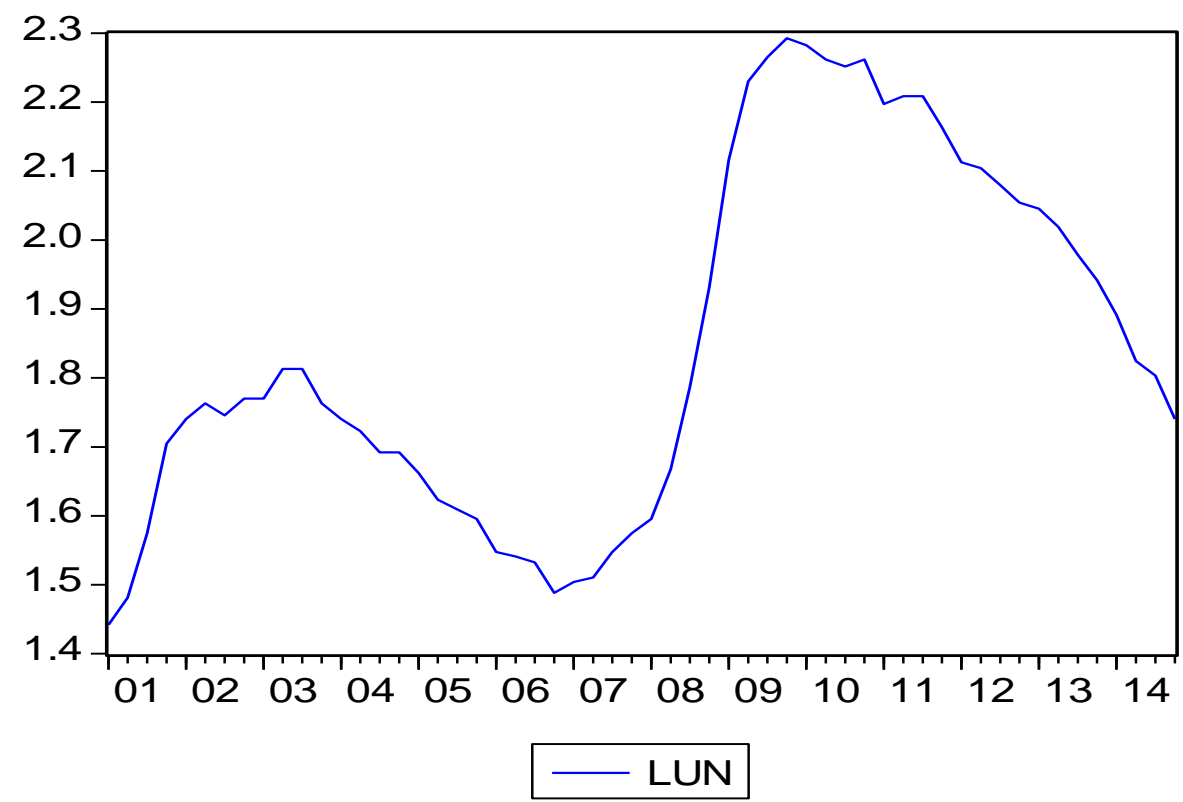

Source: $B L S$

\section{Conclusions}

This paper examines the high persistent unemployment notion of hysteresis for the US economy. Wage inflation dynamics is analyzed in Section 4 for the 1990-2014 period with NKWPC equations. Following data analysis and unit root tests, equations are estimated with unemployment/employment gap and alternatively with ROC of unemployment/employment. Additionally, NKWPC equations are estimated with $\mathrm{Y}_{\text {gap }}$ and ROC of output variables.

Estimation results are evaluated in Section 5. Although findings are not strong for level NKWPC they have implications for possible PC tradeoff. Previous findings on NKWPC together with this paper point that the PC estimations, with different data series or higher order lags will be worth analysing.

There is even weaker evidence of NKWPC with the ROC variables and the ROC of nominal/real GNP is associated with wage inflation only during the 2001 recession. Relation of wage inflation with the past behavior of GNP captured in Tables 4.c-4.d during 2001 is of a rate of change Phillips curve nature. As shocks change aggregate demand, resulting effects on the variables will persist even after first impact of the shock is gone. 
Lack of ROC Phillips curve unemployment/employment leads to the reasoning that nonstationarity detected in unemployment/employment series might be due to labour market shocks rather than demand fluctuations (or mixed effects). Nonlinear stationary tests with breaks would be useful to detect whether the series are actually nonstationary. Nonlinear estimation could also reveal the relation between wages and unemployment/employment in the studies to be conducted in the future.

Hysteresis evidence has not been too strong with stationary tests performed on US economy in the previous studies, whereas structural models have provided evidence in favor of it in Blanchard and Summers (1986), Jaeger and Parkinson (1991), Ball (1997) and Ball (1999), for the period 1953-1990 and in Yagan (2018) during 2007-2015 (see Section 3). There is still need for further research to be conducted on hysteresis before reaching a firm ground explaining its dynamics. Hysteresis has policy implications such that demand management policies (especially monetary policy) have influence on long term unemployment and wage dynamics rather than labour market arrangements etc. on the supply side. It seems that economic downturns can be "coarse tuned" via appropriate policies, reversing the persistence of unemployment. Expansionary policies are already relevant policy options for getting over recessions (Ball, 2009, 1998, 1997; Blanchard and Summers, 1986). Recently expansionary monetary and fiscal policies of European countries during the debt crisis and especially the 2008 US recession are exemplifying.

\section{APPENDIX I}

\section{Figure: 1}

Unemployment

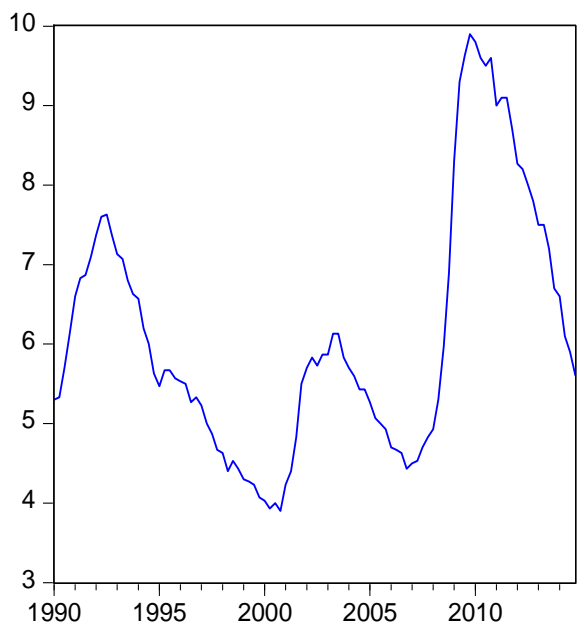

Employment Rate

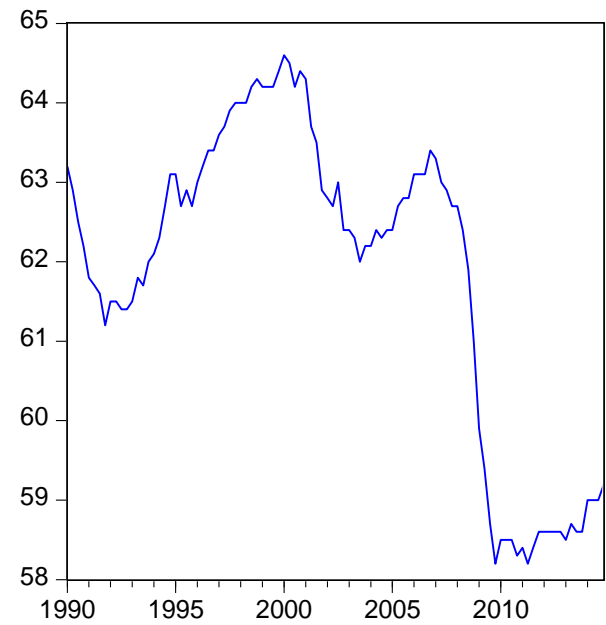


Figure: 2
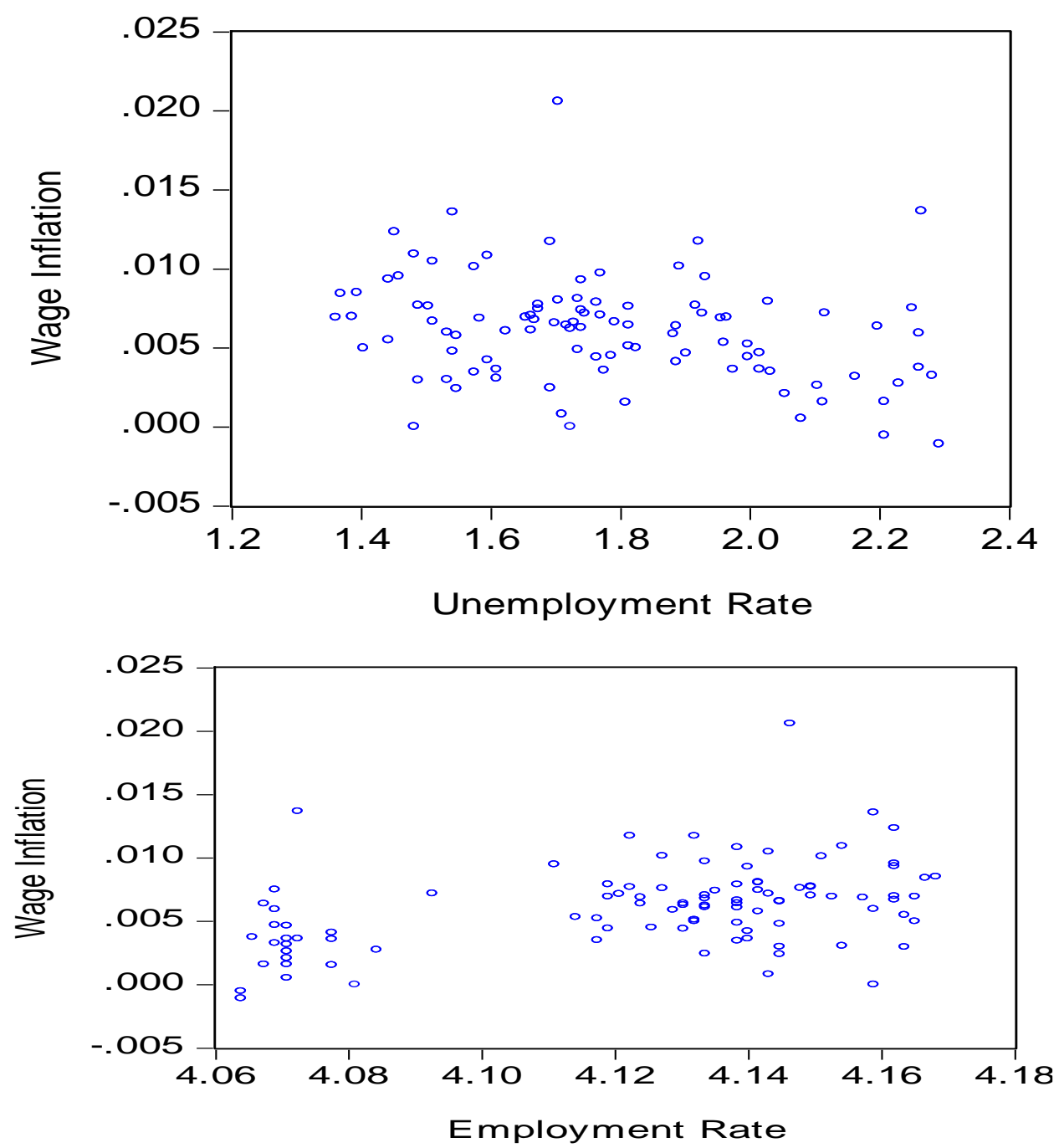


\section{Figure: 3}
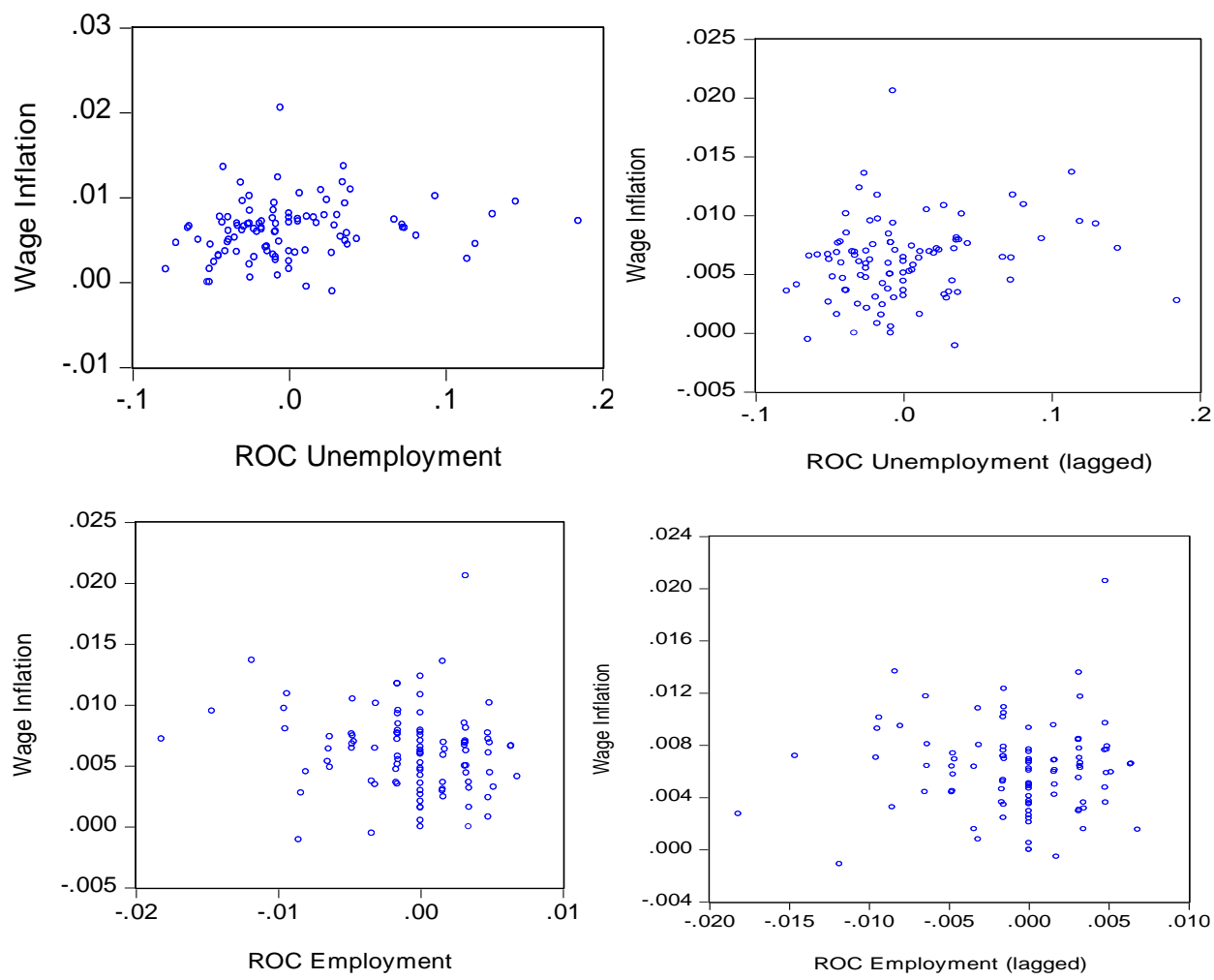

\section{References}

Arestis, P. \& I.B.F. Mariscal (2000), "OECD Unemployment: Structural Breaks and Stationarity", Applied Economics, 32(4), 399-403.

Bahmani-Oskooee, M. \& T. Chang \& O. Ranjbar (2018), "Testing Hysteresis Effect in the U.S. State Unemployment: New Evidence Using a Nonlinear Quantile Unit Root Test”, Applied Economics Letters, 25(4), 249-253.

Ball, L.M. (1997), "Disinflation and the NAIRU”, in: C.D. Romer \& D.H. Romer (eds.), Reducing Inflation, Motivation and Strategy, (NBER, Studies in Business Cycles, Volume 30), the University of Chicago Press: Chicago.

Ball, L.M. (1999), “Aggregate Demand and Long Run Unemployment”, Brooking Papers on Economic Activity, 1999(2), 189-251.

Ball, L.M. (2009), "Hysteresis in Unemployment: Old and New Evidence", NBER Working Paper, No. 14818, March.

Baştav, L. (2011), “An Empirical Study on the Wage and Price Stickiness of US Economy (19902009)”, Ekonomik Yaklaşım, 22(81), 45-64. 
Blanchard, O. (2005), "European Unemployment: The Evolution of Facts Ideas", NBER Working Paper, No. 11750, November.

Blanchard, O.J. \& L.H. Summers (1986), "Hysteresis and the European Unemployment Problem", NBER Macroeconomics Annual 1986, Cambridge: MIT Press.

Blinder, A.S. (1988), “The Fall and Rise of Keynesian Economics”, Economic Record, December 278-94.

Bureau of Economic Analysis Database (2015), <http://www.bea.gov>, March.

Bureau of Labour Statistics Database (2015), <http://www.bls.gov>, March.

Calvo, G. (1983), "Staggered Prices in a Utility Maximizing Framework”, Journal of Monetary Economics, 12(3), 383-398.

Cheng, K.M. et al. (2012), "Hysteresis vs Natural Rate of US Unemployment", Economic Modelling, 29(2), 428-434.

Cogley, T. \& A.M. Sbordone (2008), "Trend Inflation, Indexation, and Inflation Persistence in the New Keynesian Phillips Curve”, American Economic Review, 98(5), 2101-2126.

Craigwell, R. \& S.M.S. Maurin (2011), "Unemployment Hysteresis in the English-Speaking Caribbean: Evidence from Non-Linear Models", Paper presented in Ecomod 2011 International Conference on Economic Modeling, Azores, June 29 - July 1.

Friedman, M. (1968), “The Role of Monetary Policy”, American Economic Review, March 58(1), 117.

Gali, J. \& M. Gertler (1999), "Inflation Dynamics: A Structural Econometric Analysis”, Journal of Monetary Economics, 44(2), 195-222.

Gali, J. (2010), “The Return of the Wage Phillips Curve”, NBER Working Paper, No. 15758, February.

Gali, J. (2015), "Hysteresis and the European Unemployment Problem Revisited", NBER Working Paper, No. 21430.

Gordon, R.J. (1990), “What Is New Keynesian Economics?”, Journal of Economic Literature, September 28(3), 1115-71.

Gottfries, N. \& H. Horn (1987), "Wage formation and the Persistence of Unemployment", Economic Journal, December 97, 877-884.

Hargraves-Heap, S.P. (1980), “Choosing the Wrong Natural Rate, Accelerating Inflation or Decelerating Unemployment and Growth”, Economic Journal, September 90, 611-20.

Jaeger, A. \& M. Parkinson (1991), "Some Evidence on Hysteresis in Unemployment Rates", Forschungsbericht/Research Memorandum, No. 286, October.

Leon-Ledesma, M.A. (2002), "Unemployment Hysteresis in the US and the EU: A Panel Data Approach", Bulletin of Economic Research, 54(2), 95-103.

Lindbeck, A. \& D.J. Snower (1988), “Cooperation, Harassment and Involuntary Unemployment: An Insider-Outsider Approach", American Economic Review, March 78(1), 167-188.

Llaudes, R. (2008), "Unemployment and Inflation in Europe”, PhD. Dissertation, Johns Hopkins University-Maryland.

Lucas, R.E. Jr. (1996), “Nobel Lecture: Monetary Neutrality”, Journal of Political Economy, August 104(4), 666-82.

Mankiw, N.G. (1992), "The Reincarnation of Keynesian Economics”, European Economic Review, 36(2-3), April 559-65. 
Mitchell, W.F. (1993), “Testing for Unit Roots and Persistence in OECD Unemployment Rates”, Applied Economics, 25, 1489-1501.

Mohan, R. \& F. Kemegue \& F. Sjuib (2008), "Hysteresis in Unemployment: Panel Unit Roots Tests Using State Level Data", Journal of Business and Economics Research, 6(2), 53-60.

Nason, J.M. \& G.W. Smith (2008), “The New Keynesian Phillips Curve: Lessons from Single Equation Econometric Estimation”, Economic Quarterly, 94(4), 361-395.

Phelps, E.S. (1967), "Phillips Curves, Expectations of Inflation and Optimal Unemployment over Time", Economica, 34(135), August 254-281.

Phelps, E.S. (1972), Inflation Policy and Unemployment Theory, NY: Norton.

Phillips, A.W. (1958), "The Relation between Unemployment and the Rate of Change of Money Wage Rates in the United Kingdom, 1861-1957”, Economica, 25(100), November 283299.

Roed, K. (1996), “Unemployment Hysteresis - Macro Evidence from 16 OECD Countries”, Empirical Economics, 21, 589-600.

Roed, K. (1999), “A Note on the Macroeconomic Modelling of Unemployment Hysteresis”, Applied Economics Letters, 6, 255-258.

Rotemberg, J.J. (1982), "Monopolistic Price Adjustment and Aggregate Output”, The Review of Economic Studies, 49(4), 517-531.

Samuelson, P.H. \& R.M. Solow (1960), “Analytical Aspects of Anti-Inflation Policy”, American Economic Review, 50, 177-194.

Saz, G. (2011), “The Turkish Phillips Curve Experience and the New Keynesian Phillips curve: A Conceptualization and Application of a Novel Measure for Marginal Costs", International Journal of Finance and Economics, 63, 8-45.

Snowdon, B. \& H.R. Vane (1995), "New Keynesian Economics Today", American Economist, (39), Spring, 48-65.

Snowdon, B. \& H.R. Vane (1997), “The Development of Modern Macroeconomics, A Rough Guide”, in: B. Snowdon \& H.R. Vane (eds.), A Macroeconomics Reader, Routledge: New York.

Tokatlığlu, İ. \& T. Öztürk \& H.N. Ardor (2014), “AB Ülkeleri ve Türkiye İşgücü Piyasasında Histeri Etkisi: RATCHET Modeli Analizi”, Sosyoekonomi, 22(22), 297-320.

Tsangyao, C. et al. (2007), "Hysteresis in Unemployment: Empirical Evidence from Taiwan's Region Data Based on Panel Unit Root Tests", Applied Economics, (39), 1335-1340.

Yagan, D. (2018), "Employment Hysteresis from the Great Recession”, NBER Working Paper, No. 23844. 
Baştav, L. (2019), "Empirical Evidence on the US Labour Market Hysteresis: New Keynesian Wage Phillips Curve (1990-2014)", Sosyoekonomi, Vol. 27(40), 31-53. 